\title{
Osmotic priming of rice seeds subjected to low temperatures ${ }^{1}$
}

\author{
Fernanda Reolon Tonel ${ }^{2}$, Patrícia Marini ${ }^{2 *}$, Juliana de Magalhães Bandeira ${ }^{2}$, Ana \\ Carolina Silveira da Silva ${ }^{3}$, Norton Victor Sampaio ${ }^{4}$, Francisco Amaral Villela ${ }^{5}$
}

\begin{abstract}
Aiming at verifying effects of priming on germination and emergence of seeds subjected to low temperatures, rice seeds (cv. IRGA 418) were primed into a $\mathrm{KNO}_{3}$ solution during 24,48 , and $72 \mathrm{~h}$, at $20^{\circ} \mathrm{C}$; and into distilled water, for $24 \mathrm{~h}$ (control). Germination (G), first count of germination (FCG), and germination speed index (GSI) were the parameters assessed under temperatures of $17^{\circ} \mathrm{C}, 20^{\circ} \mathrm{C}$ and $25^{\circ} \mathrm{C}$. Besides, field emergence (FE), and emergence speed index (ESI) were also assessed under field conditions. A completely randomized design was used with treatments arranged in 4 x 3 factorial (treatments $\mathrm{x}$ temperatures) in all experiments. None statistically significant difference was found for seed germination within the $24 \mathrm{~h}$ imbibition period, under any of temperatures assessed; although after 48 and $72 \mathrm{~h}$, at $17{ }^{\circ} \mathrm{C}$, this variable has decreased. When seeds were imbibed in $\mathrm{KNO}_{3}$, during 48 and $72 \mathrm{~h}$, the FCG and GSI were decreased, as compared to $24 \mathrm{~h}$ imbibition period, and for control treatment, at $17{ }^{\circ} \mathrm{C}$ and $25^{\circ} \mathrm{C}$. After $24 \mathrm{~h}$ imbibition, the $\mathrm{FE}$ has not differed statistically from control treatment; as occurred for periods of 24 and $48 \mathrm{~h}$ imbibition for the ESI parameter. Priming in $\mathrm{KNO}_{3}$ does not cause beneficial effect on seed germination or on seedling emergence of rice.
\end{abstract}

Index terms: Oryza sativa, germination, emergence, conditioning, $\mathrm{KNO}_{3}$.

\section{Condicionamento osmótico em sementes de arroz submetidas à baixas temperaturas}

\begin{abstract}
RESUMO - Com o objetivo de verificar o efeito do condicionamento osmótico na germinação e emergência de sementes de arroz submetidas a baixas temperaturas, sementes de arroz cv. IRGA 418 foram condicionadas em solução de nitrato de potássio $\left(\mathrm{KNO}_{3}\right)$ por 24,48 e $72 \mathrm{~h}$, a $20{ }^{\circ} \mathrm{C}$. Como controle as sementes foram embebidas em água destilada por $24 \mathrm{~h}$. Foram realizados os testes: germinação $(\mathrm{G})$, primeira contagem (PCG) e índice de velocidade de germinação (IVG), nas temperaturas de $17{ }^{\circ} \mathrm{C}, 20^{\circ} \mathrm{C}$ e $25^{\circ} \mathrm{C}$, com fatorial $4 \times 3$ (tratamentos x temperaturas); além da emergência (EC) e do índice de velocidade de emergência (IVE), com delineamento inteiramente casualizado. Não houve diferença significativa na germinação das sementes em 24 h de embebição em nenhuma temperatura, enquanto que nos períodos de embebição de $48 \mathrm{~h}$ e $72 \mathrm{~h}$ aos 17 ${ }^{\circ} \mathrm{C}$ houve redução desta variável. A PCG e o IVG diminuíram quando as sementes foram embebidas em $\mathrm{KNO}_{3}$ por 48 h e 72 $\mathrm{h}$ comparados às $24 \mathrm{~h}$ de embebição e controle a $17{ }^{\circ} \mathrm{C}$ e $25^{\circ} \mathrm{C}$. Em $24 \mathrm{~h}$ de embebição a EC não diferiu do controle, assim como os tratamentos de $24 \mathrm{~h}$ e $48 \mathrm{~h}$ para o IVE. O condicionamento osmótico em $\mathrm{KNO}_{3}$ não promove efeito benéfico sobre a germinação e a emergência de plântulas de arroz.
\end{abstract}

Termos para indexação: Oryza sativa, germinação, emergência, priming, $\mathrm{KNO}_{3}$

\section{Introduction}

The rice is widely grown throughout the world. In Brazil, the state of Rio Grande do Sul occupies a prominent place on rice production, contributing with $50 \%$ of national output, and where $80 \%$ of the area is irrigated and most of this area is cultivated with this crop, that is characterized as the main economic activity

${ }^{1}$ Submitted on 10/04/2012. Accepted for publication on 01/30/2013 ${ }^{2}$ Departamento de Botânica, Universidade Federal de Pelotas, Caixa Postal 354, 96001-970 - Pelotas, RS, Brasil.

${ }^{3}$ Instituto Biotecnológico de Reprodução Vegetal, Universidade da Região da Campanha, 96400-350 - Bagé, RS, Brasil. of interest in the southern half of the state (Almeida et al., 2011). However, under adverse climatic conditions, some rice cultivars may exhibit slow and uneven germination, which can be related to the low temperatures that occur in the South Region of Brazil during the sowing time what depending on the cultivar, as well as of the intensity and on duration of the cold weather, may impair development of the crop (SOSBAI, 2007).

\footnotetext{
${ }^{4}$ Universidade Federal do Pampa, 96450-000 - Dom Pedrito, RS, Brasil. ${ }^{5}$ Departamento de Fitotecnia, Universidade Federal de Pelotas, Caixa Postal 354, 96010-900 - Pelotas, RS, Brasil.

*Corresponding author <marinipati@gmail.com>
} 
Cold tolerance is a characteristic highly desirable for the rice genotypes to be grown in the south of country (Cruz et al., 2010). However, the origin of most cultivars commercially used in that region is tropical, what largely contributes to reduction of productivity of rice crop in the state of Rio Grande do Sul (Mertz et al., 2009). Therefore, the choice of the sowing time is very important for obtaining a high and steady productivity levels, thus avoiding the adverse climatic periods during the stages of germination and flowering of the rice plants, which are considered critical for achievement of an elevated productivity (Steinmetz et al., 2007). Moreover, the use of an adequate density of seeding, performed with use of high quality seeds are very important for obtaining an increased productivity. The use of high vigor seeds is essential for all crops, once the aim is always the same, i.e., achieve an adequate plant population within a wide range of environmental conditions that could be found during emergence of seeds in the field, and that would be capable of enable high yields even when the density of plants is lower than density required (Scheeren et al., 2010).

In this context, it is justified the use of techniques that favor germination of the seeds and decrease the time between sowing and seedling emergence (Pereira et al., 2008). Among these techniques the priming, or physiological conditioning, is characterized by immersion of seeds during a given time period (hours or days) into an aqueous solution with osmotic potential known and previously established; and aims at reducing seed germination period, as well as synchronize and improve seedling emergence. It is also a way of subjecting seeds to a hydration control that is sufficient to allow starting the respiratory process, which is essential to germination of the seeds, but that should not be insufficient to allow protrusion of radicle during germination process (Gurgel-Junior et al., 2009). Among osmotic agents most commonly used are included the inorganic osmotic agents such as salts $\left(\mathrm{NaCl}, \mathrm{KNO}_{3}\right.$, and $\left.\mathrm{MgSO}_{4}\right)$, and organic osmotic agents such as sugars (mannitol and sorbitol), polyethylene glycol (PEG), and glycerol (Kissmann et al., 2011).

Responses to seed priming depend on factors such as: temperature; osmotic potential of the solution; duration of treatment; light intensity; and on method and drying period after treatment; besides other factors that may influence the extent of priming (Santos et al., 2008). However, beneficial effects of this technique have already been observed on melon seeds (Nascimento and Aragão, 2002), asparagus (Bittencourt et al., 2004), and papaya (Aroucha et al., 2006), among other plant species.

As previously mentioned, this technique has already been applied, mainly in horticultural vegetable seeds, aiming at increasing germination speed; and this way improving and standardizing seedling emergence, especially under adverse environmental conditions. However, little information is available in the literature regarding osmotic priming of seeds of the large crops. Whereupon the objective of this study was to investigate the effect of priming on germination and on emergence of rice seeds subjected to low temperatures.

\section{Material and Methods}

The study was conducted at the Seed Testing Laboratory of the Biotechnological Institute of Plant Reproduction, Universidade da Região da Campanha (URCAMP) (University of Region of the "Campanha"), municipality of Bagé, state of Rio Grande do Sul, Southern Brazil. Samples of rice seeds (cv. IRGA 418) were previously soaked into distilled water for $24 \mathrm{~h}$, thus constituting the control treatment. For composing the other treatments, samples with the same amount of seeds were imbibed in an aerated solution of potassium nitrate $\left(\mathrm{KNO}_{3}\right)$ during 24,48 , and $72 \mathrm{~h}$, at $20{ }^{\circ} \mathrm{C}$, in concentration of $20 \mathrm{~g} \cdot \mathrm{L}^{-1}(0.2 \mathrm{M})$ within Kitasato vials connected to an air pump (aquarium pump), that by distributing air through pipes has kept the aeration constant.

After each different period of osmotic priming, seeds were dried until their initial moisture content (12-14\%) during a $24 \mathrm{~h}$ period, at room temperature, and then stored under controlled environmental conditions $\left(15^{\circ} \mathrm{C}\right.$ temperature and $40 \%$ to $50 \% \mathrm{RH}$ ), during $72 \mathrm{~h}$. Subsequently, and according to the established by Rules for Seed Testing (Brasil, 2009), the seeds were subjected to the following assessments:

Germination test $(\mathrm{G})$ : this test has been conducted with three replications of 100 seeds each (four subsamples of 25 seeds each), totaling 300 seeds. Transparent plastic boxes $\left(\right.$ Gerbox $\left.^{\circledR}\right)$, containing two sheets of blotter paper were used to perform test. The sheets of blotting paper, which were used as substrate, were previously moistened with sterile distilled water in a ratio of 2.5 times the mass of dry substrate, and then kept into a germinator, at $17{ }^{\circ} \mathrm{C}, 20^{\circ} \mathrm{C}$ and $25^{\circ} \mathrm{C}$ temperature, and photoperiod of $8 / 16 \mathrm{~h}$ (L/D). The counting of germinated seeds were performed on the fifth and on the fourteenth day after sowing (DAS) and results were expressed as percent germination, by counting only the seedlings considered as normal.

First count of germination (FCG): this test has been performed jointly with the germination test; and the first counting was performed on the fifth DAS. Results were also expressed as percentage of normal seedlings.

Germination speed index (GSI): this test was carried out following methodology described by Maguire (1962) and conducted together with the germination test; however, the assessments were performed daily by counting as emerged only the seeds that were showing protrusion of rootlet through the seed coat, until the number of emerged seedlings has remained 
constant. The final counting date for this test was the same used for assessing the germination test; and the computation of GSI was performed using the following equation: GSI $=\mathrm{G} 1 / \mathrm{T} 1+$ $\mathrm{G} 2 / \mathrm{T} 2+\ldots+\mathrm{Gn} / \mathrm{Tn}$ (Maguire, 1962); where G1, G2, ...Gn, is the number of seedlings daily counted; and T1, T2,... Tn, is the time span for counting performed at each DAS.

Field emergence (FE): this assessment has been performed in seedbeds with three replications of 100 seeds each, per each treatment, and sowing was carried out at the time recommended for the species (October-November) into rows with approximately $1.5 \mathrm{~m}$ in length and $2.0 \mathrm{~cm}$ of deepness; by sowing 25 seeds into each row. Irrigation and removal of weeds were manually performed. The counts were initiated from the emergence of the first seedling and were concluded at 21 DAS (Brasil, 2009); and the germination speed index (GSI) was obtained by the daily counting of the seedlings, following the methodology described by Vieira and Carvalho (1994).

For the variables: G; FCG and GSI, the experimental design used was completely randomized with treatments arranged in a factorial $4 \times 3$ (4 treatments $\times 3$ temperatures); and for variables ESI and FE, the experimental design has been the same, but with treatments arranged in a completely randomized scheme. All treatment means were compared by Tukey test, at 5\% probability.

\section{Results and Discussion}

There has been no statistically significant differences for the rice seed percent germination when these seeds were osmotically primed for $24 \mathrm{~h}$ into potassium nitrate solution, or for the seeds of the control treatment (priming in distilled water), when these seeds were primed under temperatures of $17{ }^{\circ} \mathrm{C}, 20^{\circ} \mathrm{C}$, and $25{ }^{\circ} \mathrm{C}$ (Table 1). These results corroborate those results found in onion seeds (cv. Petroline) primed in distilled water at $15{ }^{\circ} \mathrm{C}$, for $48 \mathrm{~h}$, and assessed by different methods and storage periods, which have not presented advantage on percentage of seedlings in the field (Caseiro and Marcos-Filho, 2005). Likewise, for seeds of two different cultivars of cauliflower (Marcos-Filho and Kikuti, 2008) and cucumber (Gurgel-Junior et al., 2009) the priming did not change the percentage of germination, what emphasizes that this technique generally does not promote changes in germination percent (Marcos-Filho, 2005), what is consistent with data found in the literature.

Table 1. Mean values of germination (G), first count of germination (FCG), and germination speed index (GSI) of rice seeds (cv. IRGA 418) subjected to the osmotic priming with a solution of $\mathrm{KNO}_{3}$ during 24, 48 and $72 \mathrm{~h}$ under three different temperatures $\left(17^{\circ} \mathrm{C}, 20^{\circ} \mathrm{C}\right.$ and $\left.25^{\circ} \mathrm{C}\right)$.

\begin{tabular}{clllllllcc}
\hline \multirow{2}{*}{ Imbibition periods } & \multicolumn{3}{c}{$\mathrm{G}(\%)$} & \multicolumn{3}{c}{$\mathrm{FCG}(\%)$} & \multicolumn{3}{c}{$\mathrm{GSI}$} \\
\cline { 2 - 9 } & $17{ }^{\circ} \mathrm{C}$ & $20^{\circ} \mathrm{C}$ & $25^{\circ} \mathrm{C}$ & $17{ }^{\circ} \mathrm{C}$ & $20^{\circ} \mathrm{C}$ & $25{ }^{\circ} \mathrm{C}$ & $17^{\circ} \mathrm{C}$ & $20^{\circ} \mathrm{C}$ & $25^{\circ} \mathrm{C}$ \\
\hline $24 \mathrm{~h}$ & $84 \mathrm{Aa} *$ & $92 \mathrm{Aa}$ & $92 \mathrm{Aab}$ & $68 \mathrm{Ba}$ & $84 \mathrm{Aa}$ & $76 \mathrm{Aba}$ & $1.79 \mathrm{Ba}$ & $4.75 \mathrm{Aa}$ & $4.54 \mathrm{Aa}$ \\
$48 \mathrm{~h}$ & $64 \mathrm{Bb}$ & $84 \mathrm{Aab}$ & $88 \mathrm{Aab}$ & $20 \mathrm{Cb}$ & $72 \mathrm{Aa}$ & $36 \mathrm{Bb}$ & $0.99 \mathrm{Bb}$ & $4.01 \mathrm{Aa}$ & $3.90 \mathrm{Ab}$ \\
$72 \mathrm{~h}$ & $24 \mathrm{Bc}$ & $72 \mathrm{Ab}$ & $84 \mathrm{Ab}$ & $44 \mathrm{Bb}$ & $44 \mathrm{Ab}$ & $20 \mathrm{ABb}$ & $0.17 \mathrm{Bc}$ & $3.18 \mathrm{Ac}$ & $3.46 \mathrm{Ab}$ \\
Control & $88 \mathrm{Aa}$ & $92 \mathrm{Aa}$ & $96 \mathrm{Aa}$ & $52 \mathrm{Ba}$ & $68 \mathrm{ABa}$ & $88 \mathrm{Aa}$ & $1.82 \mathrm{Ba}$ & $4.18 \mathrm{Ab}$ & $4.66 \mathrm{Aa}$ \\
\hline
\end{tabular}

* Means followed by the same uppercase letter in the lines and lowercase letter in the columns are not statistically different by Tukey tests, at $5 \%$ probability.

There was statistically significant reduction on germination percent of the seeds, when the period of osmotic priming with potassium nitrate has been increased to all treatments assessed (Table 1). Due to the fact that compound is a salt, it is possible that the reduction of germination was caused by the osmotic effect of the solution on the water uptake by seeds (Souza et al., 2011). Tolerance mechanisms of the seeds subjected to salt solutions depend on ability of the protoplasm in the compartmentalization of the ions that enter the cell; however, these tolerance mechanisms on plants are not yet fully understood, once involve biochemical, physiological and molecular changes (Abreu et al., 2008).

Moreover, when the priming was applied to carrot seed and conducted during four days with polyethylene glycol (PEG 6000), which is an organic agent, there was an increase on percentage of seed germination and on speed of seedling development (Pereira et al., 2008), demonstrating that an organic agent does not promote toxic effects similar to those observed in the present study, when an inorganic agent $\left(\mathrm{KNO}_{3}\right)$ was used. In contrast, on studies conducted with seeds of Ground Cherry (Physalis angulata L.) (Souza et al., 2011) and sugar beet (Costa and Villela, 2006) physiologically primed with an organic agent, it was detected a decrease on germination percent of the seeds osmotically primed, thus corroborating results found for rice seeds, which were primed in $\mathrm{KNO}_{3}$ during periods of 48 and $72 \mathrm{~h}$, as well as a significant reduction on germination of the seeds stored in the lowest temperature $\left(17^{\circ} \mathrm{C}\right)$ (Table 1$)$.

Therefore, according to results herein achieved it possible to observe that, with increasing soaking period in $\mathrm{KNO}_{3}$ 
solution, the germination was gradually decreased, in absolute values, for almost all temperatures studied; nevertheless, a statistically significant difference has been found on the temperature of $17{ }^{\circ} \mathrm{C}$ (Table 1). However, when the seeds were subjected to priming under temperature of $25^{\circ} \mathrm{C}$, these seeds showed less sensitivity to effect of the osmotic priming, with values similar to those of the control treatment, what is probably due to the fact that this temperature is indicated to the species under study; what undoubtedly promoted a better viability to the seeds.

Oppositely, on a study conducted with bell pepper seeds it was observed beneficial effects of osmotic priming when seeds were germinated at the optimum temperature for germination; however, under sub-optimal temperatures for germination it was possible to observe statistically significant differences in responses to the osmotic priming between the control treatment, and the remaining treatments (Posse et al., 2001). The use of primed seeds is only viable when these seeds are sown under conditions of temperatures below or above the optimum; and such condition has not occurred for the germination parameter, at the temperatures of $17^{\circ} \mathrm{C}$ and $20^{\circ} \mathrm{C}$; where it was expected that the osmotic priming would be sufficient to attenuate the effects caused by cold. Although the rice may be grown under many different environmental conditions, the crop is much more sensitive to low temperatures, being this one of the major agents of abiotic stresses affecting the crop, as compared to other cereals like oats or wheat (Mertz et al., 2009).

The vigor of rice seeds assessed by FCG and GSI was significantly reduced when seeds were osmotically primed in $\mathrm{KNO}_{3}$ solution at the imbibition periods of 48 and $72 \mathrm{~h}$, as compared to treatments of $24 \mathrm{~h}$ of soaking period, and to the temperatures of $17{ }^{\circ} \mathrm{C}$ and $25^{\circ} \mathrm{C}$ of the control treatment. However, at $20{ }^{\circ} \mathrm{C}$ these variables were reduced only after $72 \mathrm{~h}$ of osmotic priming in $\mathrm{KNO}_{3}$ solution (Table 1). Similar behavior has been also observed in cauliflower seeds where positive effects of treatments on the germination rate of the seeds were detected (Marcos-Filho and Kikuti, 2008).

Different results to the osmotic priming have been detected by Nascimento (2005) on tomato seeds primed in a solution of $\mathrm{KNO}_{3}(0.30 \mathrm{M})$ during seven days, at $20{ }^{\circ} \mathrm{C}$, and on osmotic priming of watermelon seeds in aerated solution of $\mathrm{KNO}_{3}(0.35 \mathrm{M})$, at $20^{\circ} \mathrm{C}$, which have reduced germination speed when the seeds were incubated under conditions of low temperatures. Nevertheless, when the osmotic priming of Pterogyne nitens seeds was performed under low temperatures $\left(10{ }^{\circ} \mathrm{C}\right)$ its effect has been more efficient than when seeds were subjected to the same treatment, but applied at higher temperatures $\left(27^{\circ} \mathrm{C}\right)$ (Tonin et al., 2005).
In respect to percent $\mathrm{FE}$, only the seeds osmotically primed during $24 \mathrm{~h}$ had presented mean results to seed germination that were not statistically different from values obtained to the control treatment. As to the ESI, the mean with 24 and $48 \mathrm{~h}$ of osmotic priming also have not differed from the mean value obtained to the control treatment (Table 2). These results may be due to the fact that the sowing was performed on the period recommended for rice crop, i. e., the ideal temperature for the establishment of this gramineous species in the field. This way, the beneficial effects of osmotic priming were not detected when seeds were imbibed, during 48 and $72 \mathrm{~h}$, in the $\mathrm{KNO}_{3}$ solution; thus confirming data found in literature on emergence of beet seeds subjected to the osmotic priming and the pre-hydration in distilled water, which are not efficient on improving performance of those seeds (Costa and Villela, 2006). However, significant increases on percentage of emergence and on emergence speed index were also observed on Adesmia latifolia seeds, osmotically primed in a PEG 6000 solution (Suñe et al., 2002).

Table 2. Mean values of field emergence (FE) and emergence speed index (ESI) of rice seeds (cv. IRGA 418) subjected to the osmotic priming with a solution of $\mathrm{KNO}_{3}$ after three different imbibition periods $(24,48$, and $72 \mathrm{~h}$ ).

\begin{tabular}{ccl}
\hline Imbibition periods & FE (\%) & ESI (\%) \\
\hline $24 \mathrm{~h}$ & $68 \mathrm{ab}^{*}$ & $2.47 \mathrm{a}$ \\
$48 \mathrm{~h}$ & $56 \mathrm{~b}$ & $2.09 \mathrm{ab}$ \\
$72 \mathrm{~h}$ & $20 \mathrm{c}$ & $0.72 \mathrm{~b}$ \\
Control & $76 \mathrm{a}$ & $2.74 \mathrm{a}$ \\
\hline
\end{tabular}

*Means followed by same letter are not statistically different by Tukey test, at $5 \%$ probability.

The rapid emergence of the seeds in field is a very advantageous situation, once that the fast emergence entails on a lower exposure of seeds to adverse environmental factors after sowing. Furthermore, it is worthy mentioning that the high vigor of seeds provides benefits to initial performance of plants in the field (Marcos-Filho and Kikuti, 2008).

\section{Conclusions}

The osmotic priming in potassium nitrate solutions $(0.2 \mathrm{M})$ does not promote beneficial effect on germination of the rice seeds cv. IRGA 418 as well as on the emergence of the seedlings in field when performed on seeds stored under low temperatures.

\section{References}

ABREU, C.E.B.; PRISCO, J.T.; NOGUEIRA, A.R.C.; BEZERRA, M.A.; LACERDA C.F., GOMES-FILHO, E. Physiological and biochemical 
changes occurring in dwarf-cashew seedlings subjected to salt stress. Brazilian Journal of Plant Physiology, v.20, n.2, p.105-118. 2008. http:// www.scielo.br/pdf/bjpp/v20n2/v20n2a03.pdf

ALMEIDA, A.S.; CARVALHO, I.; DEUNER, C.; TILLMANN, M.A.A.; VILLELA, F.A. Bioativador no desempenho fisiológico de sementes de arroz. Revista Brasileira de Sementes, v.33, n.3, p.501-510, 2011. http:// www.scielo.br/pdf/rbs/v33n3/13.pdf

AROUCHA, E.M.M.; SILVA, R.F.; NUNES, G.H.S.; SANTOS, M.C.A. Condicionamento osmótico na germinação de sementes de mamão (Carica papaya L). Revista Caatinga, v.19, n.3, p.272-277, 2006. http://scholar.google. com.br/scholar?cluster $=4901247557741945855 \& h l=p t-b r \&$ as $\quad$ sdt $=0 \&$ as $\quad$ vis $=1$

BITTENCOURT, M.L.C.; DIAS, D.C.F.S.; ARAÚJO, E.F.; DIAS, L.A.S. Controle da hidratação para o condicionamento osmótico de sementes de aspargo. Revista Brasileira de Sementes, v.26, n.2, p.99-104, 2004. http:// www.scielo.br/pdf/rbs/v26n2/24495.pdf

BRASIL. Ministério da Agricultura, Pecuária e Abastecimento. Regras para análise de sementes. Ministério da Agricultura, Pecuária e Abastecimento. Secretaria de Defesa Agropecuária, Brasília, DF: MAPA/ACS, 2009. 395p. http://www.bs.cca.ufsc.br/publicacoes/regras\%20analise\%20sementes.pdf

CASEIRO, R.F.; MARCOS-FILHO, J. Métodos para a secagem de sementes de cebola submetidas ao condicionamento fisiológico. Horticultura Brasileira, v.23, n.4, p.887-892, 2005. http://www.scielo.br/pdf/hb/v23n4/a05v23n4.pdf

COSTA, C.J.; VILLELA, F.A. Condicionamento osmótico de sementes de beterraba. Revista Brasileira de Sementes, v.28, n.1, p.21-29, 2006. http:// www.scielo.br/pdf/rbs/v28n1/a04v28n1.pdf

CRUZ, R.P.; DUARTE, I.T.L.; CABREIRA, C. Inheritance of rice cold tolerance at the seedling stage. Scientia Agricola, v.67, n.6, p.669-674, 2010. http://www.scielo.br/pdf/sa/v67n6/v67n6a08.pdf

GURGEL JUNIOR, F.E.; TORRES, S.B.; OLIVEIRA, F.N.; NUNES, T.A. Condicionamento fisiológico de sementes de pepino. Revista Caatinga, v.22, n.4, p.163-168, 2009. http://periodicos.ufersa.edu.br/revistas/index.php/ sistema/article/view/1502/756

KISSMANN, C.; SCALON, S.P.Q.; SCALON FILHO, H.; VIEIRA, M.C. Biorregulador e pré-condicionamento osmótico na germinação de sementes e no crescimento inicial da muda de carobinha (Jacaranda decurrens subsp. symmetrifoliolata Farias \& Proença) - Bignoniaceae. Revista Brasileira de Plantas Medicinais, v.13, n.1, p.58-67, 2011. http://www.scielo.br/pdf/rbpm/ v13n1/v13n1a09.pdf

MAGUIRE, J.D. Speed of germination aid in selection and evaluation for seedling emergence and vigor. Crop Science, v.2, n.2, p.176-177. 1962. https://www.crops.org/publications/cs/abstracts/2/2/cs0020020176

MARCOS-FILHO, J.; KIKUTI, J.A.D. Condicionamento fisiológico de sementes de couve-flor e desempenho das plantas em campo. Horticultura Brasileira, v.26, n.1, p.165-169, 2008. http://www.scielo.br/pdf/hb/v26n2/07.pdf

MARCOS-FILHO, J. Fisiologia de sementes de plantas cultivadas. Piracicaba: FEALQ, 2005. 495p.

MERTZ, L.M.; HENNING, F.A.; SOARES, R.C.; BALDIGA, R.F.; PESKE, F.B.; MORAES, D.M. Alterações fisiológicas em sementes de arroz expostas ao frio na fase de germinação. Revista Brasileira de Sementes, v.31, n.2, p.254-262, 2009. http://www.scielo.br/pdf/rbs/v31n2/v31n2a31.pdf
NASCIMENTO, W.M. Condicionamento osmótico de sementes de hortaliças visando à germinação em condições de temperaturas baixas. Horticultura Brasileira, v.23, n.2, p.211-214, 2005. http://www.scielo.br/pdf/hb/v23n2/25055.pdf

NASCIMENTO, W.M.; ARAGÃO, F.A.S. Condicionamento osmótico de sementes de melão: absorção de água e germinação em diferentes temperaturas. Revista Brasileira de Sementes, v.24, n.1, p.153-157. 2002. http://www.scielo.br/pdf/rbs/v24n1/v24n1a22.pdf

PEREIRA, M.D.; DIAS, D.C.F.S.; DIAS, L.A.S.; ARAÚJO, E.F. Germinação e vigor de sementes de cenoura osmocondicionadas em papel umedecido e solução aerada. Revista Brasileira de Sementes, v.30, n.2, p.137-145, 2008. http://www.scielo.br/pdf/rbs/v30n2/a17v30n2.pdf

POSSE, S.C.P.; SILVA, R.F.; VIEIRA, H.D.; CATUNDA, P.H.A. Efeito do condicionamento osmótico e da hidratação na germinação de sementes de pimentão (Capsicum annuum L.) submetidas a baixa temperatura. Revista Brasileira de Sementes, v.23, p.123-127, 2001. http://www.abrates.org.br/ revista/artigos/2001/v23n1/artigo17.pdf

SANTOS, M.C.A.; AROUCHA, E.M.M.; SOUZA, M.S.; SILVA, R.F.; SOUSA, P.A. CONDICIONAMENTO OSMÓTICO DE SEMENTES Revisão de Literatura. Revista Caatinga, v.21, n.2, p.1-06, 2008. http:// redalyc.uaemex.mx/redalyc/pdf/2371/237117611033.pdf

SCHEEREN, B.R.; PESKE, S.T.; SCHUCH, L.B.; BARROS, A.C.A. Qualidade fisiológica e produtividade de sementes de soja. Revista Brasileira de Sementes, v.32, n.3, p.35-41, 2010. http://www.scielo.br/pdf/rbs/v32n3/v32n3a04.pdf

SOSBAI - SOCIEDADE SUL-BRASILEIRA DE ARROZ IRRIGADO. Arroz Irrigado: recomendações técnicas da pesquisa para o sul do Brasil. CONGRESSO BRASILEIRO DE ARROZ IRRIGADO,5., REUNIÃO DA CULTURA DO ARROZ IRRIGADO. 27. Pelotas: SOSBAI, 2007, 161p. http://www.agencia.cnptia.embrapa.br/repositorio/recomendacoes_tecnicas_ arroz_2007_000fzrbdd8b02wx5ok0cpoo6adaexge2.pdf

SOUZA, M.O.; SOUZA, C.L.M.; PELACANI, C.R. Germinação de sementes osmocondicionadas e não osmocondicionadas e crescimento inicial de Physalis angulata L. (Solanaceae) em ambientes salinos. Revista Acta Botânica Brasílica, v.25, n.1, p.105-112. 2011. http://www.scielo.br/pdf/abb/v25n1/13.pdf

SUÑÉ, A.D.; FRANKE, L.B.; SAMPAIO, T.G. Efeitos do condicionamento osmótico na qualidade fisiológica de sementes de Adesmia latifolia (Spreng.) Vog. Revista Brasileira de Sementes, v.24, n.1, p.18-23, 2002. http://www. scielo.br/pdf/rbs/v24n1/v24n1a04.pdf

STEINMETZ, S.; FAGUNDES, P.R.R.; MARIOT, C.H.P.; WREGUE, M.S.; MATZENAUER, R.; MALUF, J.R.T.; FERREIRA, J.S.A Zoneamento Agroclimático do Arroz Irrigado por Épocas de Semeadura no Estado do Rio Grande do Sul. (Versão 4). Pelotas: EMBRAPA-CPACT, 2007. 40p. (Documentos,199). http://www.cpact.embrapa.br/publicacoes/ download/documentos/documento_199.pdf

TONIN, G.A.; GATTI, A.B.; CARELLI, B.P.; PEREZ, S.C.J.G.A. Influência da temperatura de condicionamento osmótico na viabilidade e no vigor de sementes de Pterogyne nitens Tull. Revista Brasileira de Sementes, v.27, n.2, p.35-43, 2005. http://www.scielo.br/pdf/rbs/v27n2/a06v27n2.pdf

VIEIRA, R.D.; CARVALHO, N.N. Testes de vigor em sementes. Jaboticabal: UNESP, 1994. 164p. 